\title{
H
} Forensic, Legal \& Investigative Sciences

\section{DNA Tools to Establish \\ Species and Individual \\ Identity of Confiscated \\ Biological Samples in Wildlife Related Crime: A Case Report}

\author{
Noopur Modi, Ara Sreenivas, Wajeeda Tabasum and Ajay \\ Gaur*
}

Laboratory for the Conservation of Endangered Species (LaCONES), CSIR-Centre for Cellular and Molecular Biology, Hyderabad, India

\begin{abstract}
DNA techniques are prominently used in forensic investigations involving poaching and illegal trade of endangered animals. In the present case study, we could establish the link between crime scene and seized samples successfully using DNA markers. Three persons were caught, while trespassing the forest area near Badmalhera, Madhya Pradesh, India. Range forest officer seized skin and flesh of wild animal from these persons. The officer also found blood stains on stones and leaves at the suspected spot of crime. The samples seized from the accused and those collected from the crime spot were forwarded to our laboratory to identify species and to establish relatedness amongst the samples, if any. Species identification was done using universal primers' for mitochondrial cytochrome b gene. All the forwarded samples were found to be of same species i.e., Indian spotted deer. Further, genotyping with eight polymorphic microsatellites revealed that the samples seized from the accused were similar to blood stains found at the crime spot.

Keywords: Cytochrome b; Individual identification; Microsatellites; Species identification; Wildlife forensics
\end{abstract}

\section{Introduction}

Conservation and protection assumes greater significance in the present scenario because of increased pressure on forest and the monetary value involved in the wildlife trade. India plays a major role in illegal wildlife trade as an importer, exporter and a conduit for wildlife that enters the $\$ 25$ billion annual global trade [1,2].

*Corresponding author: Ajay Gaur, Laboratory for the Conservation of Endangered Species (LaCONES), CSIR-Centre for Cellular and Molecular Biology, Hyderabad, India, Tel: +91 4024006433; E-mail: agaur@ccmb.res.in

Citation: Modi N, Sreenivas A, Tabasum W, Gaur A (2015) DNA Tools to Establish Species and Individual Identity of Confiscated Biological Samples in Wildlife Related Crime: A Case Report. J Forensic Leg Investig Sci 2: 006.

Received: November 02, 2015; Accepted: December 19, 2015; Published: January 05,2016
The greatest challenges for enforcement agencies are to detect illegal poaching and trading of wildlife and to obtain concrete evidence for the same. DNA Forensics has become a major tool in wild life crime investigation [3]. DNA analysis is not limited to only species identification but use of DNA for individual identification in wildlife forensic applications has also increased significantly [4]. This involves investigation to determine if two confiscated samples are from the same individual, to determine the pedigree of a particular individual or for questions requiring assignment to population of origin $[5,6]$.

In this case, both mitochondrial cytochrome b (cyt b) and nuclear microsatellites were used to establish the species and individual identity to link the evidences collected from the spot of crime and seized from the accused.

\section{Material and Methods}

\section{Case report}

Three persons were caught while trespassing through the forest area at Badamalehra range in Madhya Pradesh. Skin and flesh of wild animal were seized from them. The investigating range forest officer also found blood stains on stones and leaves at the suspected spot of crime. Investigation team collected blood scrapings from the spot and forwarded them along with seized flesh and skin to our lab for species and individual identification. The case was registered as CCMB/WLFC-811 and the samples were given sample codes i.e., WL-1751 to WL-1754, where 'WL' stands for Wildlife.

\section{DNA isolation}

Blood scraping from the surface of the stones (WL-1751) and leaves (WL-1752) were directly transferred to $500 \mu \mathrm{l}$ of blood lysis buffer [0.32 mM Sucrose, $10 \mathrm{mM} \mathrm{MgCl}_{2}, 10 \mathrm{mM}$ Tris $\mathrm{HCl}, 50 \mathrm{mM}$ EDTA (pH 8.0), $30 \mu \mathrm{l}$ of $20 \%$ SDS, $20 \mu \mathrm{l}$ of $20 \mathrm{mg} / \mathrm{ml}$ Proteinase K]. Piece of Flesh (WL-1753) and Skin (WL-1754) were given PBS (Phosphate Buffer Saline) wash for overnight to remove impurities like soil and dirt particles. After, complete washing, they were finely chopped and transferred to lysis buffer ( $50 \mathrm{mM}$ Tris $\mathrm{HCl}(\mathrm{pH} 8.0), 10$ mM EDTA (pH 8.0), $100 \mathrm{mM} \mathrm{NaCl}, 30 \mu \mathrm{l}$ of $20 \%$ SDS and $20 \mu \mathrm{l}$ of 20 $\mathrm{mg} / \mathrm{ml}$ Proteinase $\mathrm{K}$ ). The samples in lysis buffer were briefly vortexed and incubated at $52^{\circ} \mathrm{C}$ for $8 \mathrm{hrs}$ with gentle rotation. After complete lysis, the samples were processed for DNA isolation using the conventional Phenol- chloroform method [7]. The DNA was dissolved in TE buffer (10 mM Tris, $1 \mathrm{mM}$ EDTA, $\mathrm{pH}$ 8.0) and quantified using NanoDrop $2000^{\mathrm{TM}}$ UV-Vis spectrophotometer. DNA quality was checked by visualizing it in $0.8 \%$ agarose gel.

\section{Species identification}

The DNA obtained from all the above samples was amplified using the 'Universal Primers' [8] to generate the species-specific molecular signature. The amplification was carried out in $20 \mu \mathrm{l}$ reaction volume, using $20 \mathrm{ng}$ of template DNA, $100 \mu \mathrm{m}$ of each d NTPs, 5 pmol of each primer (Bioserve, Hyderabad, India), $1.5 \mathrm{mM} \mathrm{MgCl}, 1 \mathrm{X}$ of PCR buffer (10 mM Tris $\mathrm{HCl}, \mathrm{pH} 8.3$ and $50 \mathrm{mM} \mathrm{KCl})$. The PCR conditions were: initial denaturation at $95^{\circ} \mathrm{C}$ for $10 \mathrm{mins}$, followed by 35 cycles each of denaturation at $95^{\circ} \mathrm{C}$ for $45 \mathrm{sec}$, annealing at $52^{\circ} \mathrm{C}$ for $50 \mathrm{sec}$ 

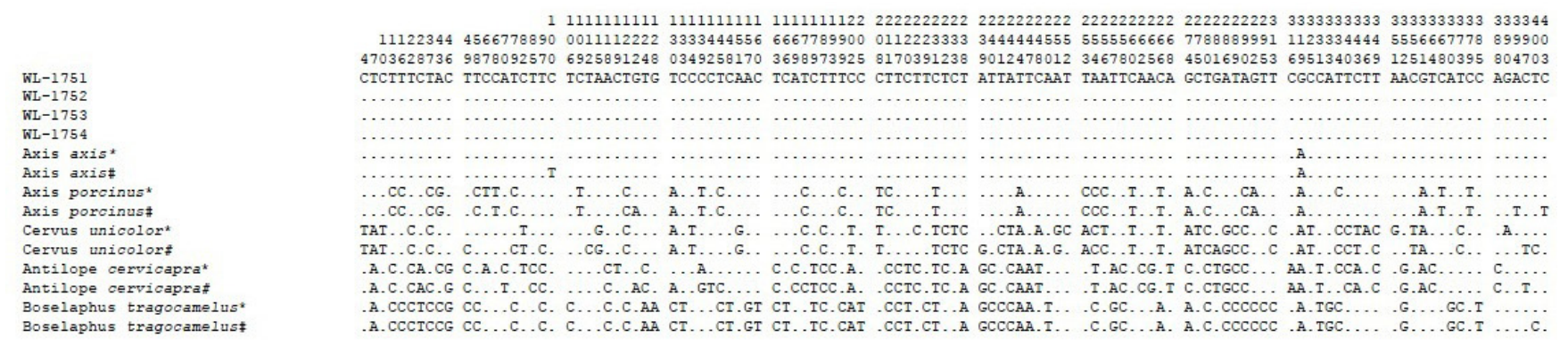

Table 1: Comparisons of cytochrome b sequences generated from the seized samples with the sequences of reference animals of major Indian ungulate species involved in wildlife related crime in India. Only variable sites are shown. (Number at top represents variable positions).

${ }^{*}$ Reference sequences from In-house database

\#Reference sequences obtained from NCBI Genbank (JN093092.1, AY035874.1, FJ556575.1, AF022058.1, and AJ222679.1)

and extension at $72^{\circ} \mathrm{C}$ for $1 \mathrm{~min}$. The final extension was at $72^{\circ} \mathrm{C}$ for 10 mins. PCR products were visualized in $2 \%$ agarose gel along with 100 bp DNA ladder (Invitrogen ${ }^{\mathrm{TM}}$, USA) to confirm the correct amplicon size. All successfully amplified PCR products obtained were sequenced (ABI 3730) on both strands in triplicates and sequences were aligned using the program Sequencing Analysis 5.2 and Codon Code alligner. Statistical confidence of sequence similarity within and among species was further assessed using a Basic Local Alignment Search Tool (BLAST) [9]. The sequence resolved was compared using MEGA 6.0 [10] with the molecular signatures of the vast number of known animal species (available in database of molecular signature generated and maintained by $\mathrm{CCMB}$ ) and sequences of closely related Indian species available in mitobase of NCBI. All the aligned sequences for the cyt $b$ showed the maximum sequence similarity with the cyt $\mathrm{b}$ sequence of Axis axis i.e., Indian spotted deer (Table 1).

\section{Individual identification}

After species identification, all the DNA samples along with one positive control (DNA of a known Indian spotted deer) and one negative control (No DNA) were subjected to PCR amplification using 8 microsatellite loci. All the 8 loci (Ca13, Ca18, Ca30, Ca38, Ca42, Ca60, Ca71 and Ca75) are deer-specific [11]. PCR amplification was carried out in $20 \mu \mathrm{l}$ of reaction mixture containing $30 \mathrm{ng}$ of genomic DNA, 1XPCR buffer, $100 \mu \mathrm{M}$ dNTPs, $1.5 \mathrm{mM} \mathrm{MgCl}_{2}, 5$ pmoles of each primer, and 0.5 units of amplitaq gold (Applied Biosystems, USA). The reaction conditions were: initial denaturation at $95^{\circ} \mathrm{C}$ for $10 \mathrm{~min}$, denaturation at $94^{\circ} \mathrm{C}$ for $45 \mathrm{~s}$; annealing at $51^{\circ} \mathrm{C}$ to $61^{\circ} \mathrm{C}$ for $50 \mathrm{~s}$; and extension at $72^{\circ} \mathrm{C}$ for $1 \mathrm{~min}\left(30\right.$ cycles) with final extension at $72^{\circ} \mathrm{C}$ for 7 mins. Forward primers were fluorescence labeled. The PCR reaction was repeated three times and visualized in $2 \%$ agarose gel along with $100 \mathrm{bp}$ DNA ladder (Invitrogen ${ }^{\mathrm{TM}}$, USA) to confirm the correct amplicon size. All amplified PCR products were size fractionated and visualized on ABI 3770 DNA sequencer. The allele size was determined using Genemapper ${ }^{\mathrm{TM}}$ software version 3.1 (Applied Biosystems, USA). The multi-locus genotype profiles of all the samples were subjected to relatedness testing by calculating Likelihood Relatedness (LR) using ML-relate software [12]. The multi-locus genotypes of other known individual Indian spotted deer were also used to compare the LR values.

\section{Results and Discussion}

In the present study, high molecular weight DNA was obtained from all the four samples namely WL-1751, WL-1752, WL-1753 and WL-1754. The cyt b sequences obtained for all four samples were aligned and compared with cyt $\mathrm{b}$ sequences of the vast number of known animal species in CCMB database and closely related Indian species i.e., Axis axis, Axis porcinus, Cervus unicolor, Antelope cervicapra and Boselaphus tragocamelus available in

\begin{tabular}{|c|c|c|c|c|c|c|c|c|c|c|c|c|c|c|c|}
\hline & & 1 & 2 & 3 & 4 & 5 & 6 & 7 & 8 & 9 & 10 & 11 & 12 & 13 & 14 \\
\hline 1 & WL 1751 & 0 & 0 & 0 & 0 & 1 & 2 & 33 & 34 & 50 & 53 & 58 & 60 & 63 & 64 \\
\hline 2 & WL 1752 & 100 & 0 & 0 & 0 & 1 & 2 & 33 & 34 & 50 & 53 & 58 & 60 & 63 & 64 \\
\hline 3 & WL 1753 & 100 & 100 & 0 & 0 & 1 & 2 & 33 & 34 & 50 & 53 & 58 & 60 & 63 & 64 \\
\hline 4 & WL 1754 & 100 & 100 & 100 & 0 & 1 & 2 & 33 & 34 & 50 & 53 & 58 & 60 & 63 & 64 \\
\hline 5 & Axis axis & 99.8 & 99.75 & 99.75 & 99.75 & 0 & 1 & 32 & 33 & 49 & 52 & 57 & 59 & 62 & 63 \\
\hline 7 & Axis porcinus & 91.9 & 91.85 & 91.85 & 91.85 & 92.1 & 91.85 & 0 & 5 & 49 & 49 & 68 & 66 & 58 & 59 \\
\hline 8 & A. porcinus (AY035874.1) & 91.6 & 91.6 & 91.6 & 91.6 & 91.9 & 91.6 & 98.77 & 0 & 52 & 52 & 72 & 65 & 61 & 62 \\
\hline 9 & Cervus unicolor & 88.6 & 88.64 & 88.64 & 88.64 & 88.9 & 88.64 & 87.9 & 87.2 & 0 & 14 & 67 & 67 & 73 & 74 \\
\hline 10 & C. unicolor (FJ556575.1) & 87.7 & 87.65 & 87.65 & 87.65 & 87.9 & 87.65 & 87.9 & 87.2 & 96.5 & 0 & 65 & 63 & 68 & 67 \\
\hline 11 & Antelope cervicapra & 85.9 & 85.93 & 85.93 & 85.93 & 86.2 & 85.93 & 84.2 & 83.2 & 84 & 84 & 0 & 14 & 55 & 56 \\
\hline 12 & A. cervicapra (AF022058.1) & 85.4 & 85.43 & 85.43 & 85.43 & 85.7 & 85.43 & 84.69 & 84.9 & 84 & 84 & 96.5 & 0 & 56 & 57 \\
\hline 14 & B. tragocamelus (AJ222679.1) & 84.4 & 84.44 & 84.44 & 84.44 & 84.7 & 84.44 & 85.93 & 85.2 & 82.7 & 84 & 86.2 & 85.9 & 100 & 0 \\
\hline
\end{tabular}

Table 2: Number of variable sites (above diagonal) and percent similarity (below diagonal) amongst cytochrome $b$ sequences generated by universal primers from the seized samples $(1,2,3,4)$ with reference sequences of closely related Indian species from CCMB in house database $(5,7,9,11,13)$ and NCBI database $(6,8,10,12,14)$. 
Citation: Modi N, Sreenivas A, Tabasum W, Gaur A (2015) DNA Tools to Establish Species and Individual Identity of Confiscated Biological Samples in Wildlife Related Crime: A Case Report. J Forensic Leg Investig Sci 2: 006.

- Page 3 of $3 \cdot$

mitobase of NCBI (Respective accession numbers were JN093092.1, AY035874.1, FJ556575.1, AF022058.1, and AJ222679.1), using MEGA 6.0. Sequence comparison shows total 116 variations in total (Table 1) and pairwise comparisions differentiated all investigated species by a minimum of 33 nucleotide variations and the sequences obtained from seized samples showed maximum similarity (>99\%) with Axis axis i.e., Indian spotted deer (Table 2).

Further, eight pairs of microsatellite loci were successfully amplified in all samples and showed the presence of same allele for each locus (Table 3). The relationship calculated between four samples by estimation of LR value was 1.00 , which indicates that the blood stains on stones, leaves and samples seized from the accused belonged to same individual animal. For reference, the LR values between the four samples and other Indian spotted deer available in CCMB in-house database was 0.00 , which proves the significant similarity at the level of microsatellite loci. Based upon the forensic evidences obtained, the accused were taken into custody under Indian Wildlife Protection Act (1973) for wildlife poaching and cruelty towards wild animals. We could detect the crime more effectively and establish a link between the evidences and the suspect with a significant degree of confidence. This particular case report once again emphasizes the role of DNA tools in the fight against poaching of endangered and protected species.

\begin{tabular}{|l|c|c|c|c|c|c|c|c|}
\hline \multirow{3}{*}{ Locus } & \multicolumn{2}{|c|}{ WL-1751 } & \multicolumn{2}{c|}{ WL-1752 } & \multicolumn{2}{c|}{ WL-1753 } & \multicolumn{2}{c|}{ WL-1754 } \\
\cline { 2 - 9 } & $\begin{array}{c}\text { Allele } \\
\mathbf{1}\end{array}$ & $\begin{array}{c}\text { Allele } \\
\mathbf{2}\end{array}$ & $\begin{array}{c}\text { Allele } \\
\mathbf{1}\end{array}$ & $\begin{array}{c}\text { Allele } \\
\mathbf{2}\end{array}$ & $\begin{array}{c}\text { Allele } \\
\mathbf{1}\end{array}$ & $\begin{array}{c}\text { Allele } \\
\mathbf{2}\end{array}$ & $\begin{array}{c}\text { Allele } \\
\mathbf{1}\end{array}$ & $\begin{array}{c}\text { Allele } \\
\mathbf{2}\end{array}$ \\
\hline Ca13 & 210 & 218 & 210 & 218 & 210 & 218 & 210 & 218 \\
\hline Ca18 & 128 & 128 & 128 & 128 & 128 & 128 & 128 & 128 \\
\hline Ca30 & 301 & 307 & 301 & 307 & 301 & 307 & 301 & 307 \\
\hline Ca42 & 128 & 150 & 128 & 150 & 128 & 150 & 128 & 150 \\
\hline Ca38 & 172 & 190 & 172 & 190 & 172 & 190 & 172 & 190 \\
\hline Ca60 & 320 & 320 & 320 & 320 & 320 & 320 & 320 & 320 \\
\hline Ca71 & 311 & 327 & 311 & 327 & 311 & 327 & 311 & 327 \\
\hline Ca75 & 190 & 202 & 190 & 202 & 190 & 202 & 190 & 202 \\
\hline
\end{tabular}

Table 3: Observed allele size in Base Pair (bp) in four confiscated samples.

\section{Acknowledgement}

The authors would like to acknowledge the financial support from CSIR and CZA, Government of India.

\section{References}

1. Menon V, Kumar A (1999) Wildlife Crime: An enforcement Guide, Natraj Publisher, Dehra Dun, India.

2. International Consortium on combating wildlife crime (2013) CITES Progress Report. Convention on International Trade in Endangered Species of wild Fauna and Flora, Geneva Switzerland.

3. Gaur A, Singh CS, Sreenivas A, Singh L (2012) DNA-based identification of a snake in a wine bottle using universal primers: a case of mistaken identity. Forensic Sci Int 214: 51-53.

4. Johnson RN, Wilson-Wilde L, Linacre A (2014) Current and future directions of DNA in wildlife forensic science. Forensic Sci Int Genet 10: 1-11.

5. Gaur A, Reddy A, Annapoorni S, Satyarebala B, Shivaji S (2005) The origin of Indian star tortoises (Geochelone elagans) based on nuclear and mitochondrial DNA analysis: a story of rescue and repatriation. Conser Genet 7: 231-240.

6. Singh A, Gaur A, Shailaja K, Satyare Bala B, Singh L (2004) A novel microsatellite (STR) marker for forensic identification of big cats in India. Forensic Sci Int 141: 143-147.

7. Sambrook J, Fristish EF, Maniatis T (1989) Molecular Cloning: A laboratory manual. ( $2^{\text {nd }}$ edn), Cold Spring Harbor Press, New York, USA 1: 40-41.

8. Verma SK, Singh L (2003) Novel universal primers establish identity of enormous number of animal species for forensic application. Mol Ecol Notes 3: 28-31.

9. http://www.ncbi.nlm.nih.gov/sites/entrez?db=nucleotide

10. Kumar S, Nei M, Dudley J, Tamura K (2008) MEGA: a biologist-centric software for evolutionary analysis of DNA and protein sequences. Brief Bioinform 9: 299-306

11. Gaur A, Singh A, Arunabala V, Umapathy G, Shailaja K, et al. (2003) Development and characterization of 10 novel microsatellite markers from Chital deer (Cervus axis) and their cross-amplification in other related species. Mol Ecol Notes 3: 607-609.

12. Kalinowski ST, Wagner AP, Mark TL (2006) ML-RELATE: a computer program for maximum likelihood estimation of relatedness and relationship. Mol Ecol Notes 6: 576-579. 